https://dx.doi.org/10.4314/ijs.v20i2.10

Ife Journal of Science vol. 20, no. 2 (2018)

\title{
PREVALENCE OF HYDATIDOSIS AND FERTILITY OF HYDATID CYST IN SLAUGHTERED CAMELS IN MAIDUGURI, NIGERIA
}

\author{
Igwenagu, E. ${ }^{1}$; Onyiche, E. T. ${ }^{2}$; Saidu, A. M. ${ }^{3}$; Chahari, A. M. ${ }^{1}$; Waziri, A. ${ }^{1}$; Kayeri, B. K. ${ }^{2}$ \\ ${ }^{1}$ Department of Veterinary Pathology, University of Maiduguri, Maiduguri, Nigeria \\ ${ }^{2}$ Department of Veterinary Parasitology and Entomology, University of Maiduguri, Maiduguri, Nigeria. \\ ${ }^{3}$ Department of Veterinary Surgery and Radiology, University of Maiduguri, Maiduguri, Nigeria \\ *Author for correspondence. E-mail: eonyiche@yahoo.com, Tel:+2348037035135 \\ (Received: $9^{\text {th }}$ November, 2017; Accepted: $19^{\text {th }}$ May, 2018)
}

\section{ABSTRACT}

\begin{abstract}
The study was conducted to determine the presence of hydatid cyst disease in slaughtered camels at the Maiduguri metropolitan abattoir. Four hundred and four (404) camels (162 males and 242 females) were examined at post mortem by visual inspection and palpation for evidence of cystic hydatidosis and fertility of the cyst. The prevalence was determined based on the sex and location of the cyst. An overall prevalence of 7 $(1.73 \%)$ was recorded. Based on sex, $2(1.20 \%)$ and $5(2.10 \%)$ were found for males and females respectively. Location of the cyst shows that lungs were the most predominant site with a value of $7(100.00 \%)$, with none found in the liver and kidneys. The entire collected cysts were fertile and characterized by the presence of protoscoleces. Despite the low prevalence, the zoonotic importance of the disease is still of public health concern.
\end{abstract}

Keywords: Hyadatid cyst, Camel, Maiduguri, Prevalence, Organ, Kidney

\section{INTRODUCTION}

Hydatidosis is an important parasitic zoonotic disease caused by the metacestode (hydatid cyst) stage of the dog tapeworm Echinicoccus granulosus (Soulsby, 1982). This disease has a worldwide distribution and is commonly seen in developing and undeveloped countries of the world.

The infection represents a medical, veterinary and economic importance in endemic areas due to its public health importance to humans, morbidity to the animals as well as organ and meat condemnation at meat inspection in the abattoir (Schantz et al., 1990).

Hydatid cysts have been seen in a wide range of mammals, including domestic ruminants, camels, giraffes, pigs, equines, elephants, hippopotamuses, marsupials and different types of deer, as well as humans (FAO, 1982; Raush, 1986). The most reliable diagnostic method is cyst detection during meat inspection or at post-mortem examination via visualization and palpation for dead animals (Dada and Belino, 1978), while serology and ultrasonography is the best for living animals. The cysts are most commonly found in the liver, lungs and spleen of domestic animals.

The one- humped camel (Camelus dromedarius) is an important multi-purpose animal in arid and semiarid areas of the world. They are kept for a variety of purposes like transportation and racing (Osuobeni and Hamidzada, 1999) and as source of human food (Dorman, 1986). The camel population in Borno state comprises mostly of those being traded between Niger and Chad Republics mostly serving as a means of transport, food in terms of meat and milk (Biu and Abbagana 2007).

Prevalence studies of the disease in camel have been carried out in various parts of the world such as Iran (Moghaddar et al., 1992), Libya (Kassem and Gdoura, 2006) and India (Srivastava et al., 1983). In Nigeria, prevalence studies have been carried out in Sokoto by Magaji et al. (2011) and Okolugbo et al. (2013) and previously in Maiduguri (Adamu and Ajogi, 1998). Therefore, the aim of this study is to provide an update on the prevalence of cystic hydatidosis in slaughtered camels in the Maiduguri metropolitan abattoir in Borno state, Nigeria.

\section{MATERIALS AND METHODS}

\section{Study area}

Borno state with Maiduguri as its capital lies between latitude $10.20 \mathrm{~N}$ and $13.40 \mathrm{~N}$ longitude $9.80 \mathrm{E}$ and $14.40 \mathrm{~N}$ with an area of $69,436 \mathrm{sq} \mathrm{km}$ 
located in the North eastern corner of Nigeria sharing borders with Niger to the north, Chad to the northeast and Cameroun to the east (Musa and Pindar, 2005). The state has Sahel vegetation in the north and Sudan savanna in the south. The Maiduguri metropolitan abattoir is located in Maiduguri, the capital of Borno state.

\section{Sample collection}

Samples were collected in the months of December, 2012 to January 2013. Samples were collected from a total of 404 slaughtered camels. The abattoir was visited periodically to examine the liver, lungs, kidney, spleen and other organs of slaughtered camels for the presence of cystic Echinococcosis. All camels presented on each visit day were examined. Each organ was assessed macroscopically by visual inspection and palpation and the sex and organ where the cyst was recovered were recorded. The suspected cysts were collected in 10\% formalin and taken to the Veterinary Parasitology Laboratory, University of Maiduguri for identification using the description of Soulsby (1982).

\section{Determination of cyst fertility}

Individual cysts were grossly examined for degeneration and calcification. Then, non calcified hydatid cysts selected for fertility study. The cyst wall was incised with sterile scalpel blade and the content was transferred into a sterile container. The content was examined under a microscope $(40 \mathrm{x})$ for the presence of protoscoleces. The cysts which contained no protoscolex were considered as infertile cysts while the presence of protoscoleces was considered as indication of fertility (Macpherson etal., 1985).

\section{Statistical analysis:}

Simple percentage and a Chi-Squared test were used to statistically analyze the data generated from the study.

\section{RESULTS}

The result of the prevalence of hydatidosis in slaughtered camel is presented in table 1 and 2 . Out of 404 camel examined, only 7 were positive giving an overall prevalence of $1.73 \%$.

Table 1 shows the result of sex-specific prevalence of hydatidosis in slaughtered camels. Out of 404 camels that were examined, $162(40.10 \%)$ were males and $242(59.90 \%)$ were females. Of the 162 males examined, $2(1.20 \%)$ were infected while 5 $(2.1 \%)$ females were infected out of 242 females. There was no statistically significant association between sex and cystic hydatidosis in camel $\left(\chi^{2}=0.3941, p=0.2651\right)$. The result of organ specific prevalence of cystic hydatidosis in slaughtered camels in Maiduguri is presented in table 2. The survey showed a prevalence of hydatidosis based on organ infected to be 7 $(1.73 \%)$ out of the 404 camels sampled with all being in the lungs and none found in the liver and kidney. There was statistically significant association between cystic hydatidosis and the organs found $\left(\chi^{2}=14.08, p=0.0009\right)$.

\section{Cyst fertility}

All the seven (7) cysts recovered from the lungs were fertile. On examination through the microscope, it was characterized by the presence of protoscoleces (hydatid sand) in the vesicular fluid (Figure 1).

Table 1: Sex specific Prevalence of Hydatidosis in Slaughtered Camels in Maiduguri

\begin{tabular}{lll}
\hline Sex of Camel & No of camel examined & $\begin{array}{l}\text { No of camel infected } \\
(\%)\end{array}$ \\
\hline Male & 162 & $2(1.20)$ \\
Female & 242 & $5(2.10)$ \\
Total & 404 & $7(1.73)$ \\
\hline
\end{tabular}

Table 2: Organ Specific Prevalence of Hydatidosis in Slaughtered Camels in Maiduguri

\begin{tabular}{llll}
\hline Sex of Camel & \multicolumn{2}{c}{ Organs Found } \\
\cline { 2 - 4 } Male & Lungs & Liver & Kidney \\
Female & $2(28.6)$ & $0(0)$ & $0(0)$ \\
Total & $5(71.4)$ & $0(0)$ & $0(0)$ \\
& $7(100)$ & $0(0)$ & $0(0)$ \\
\hline
\end{tabular}




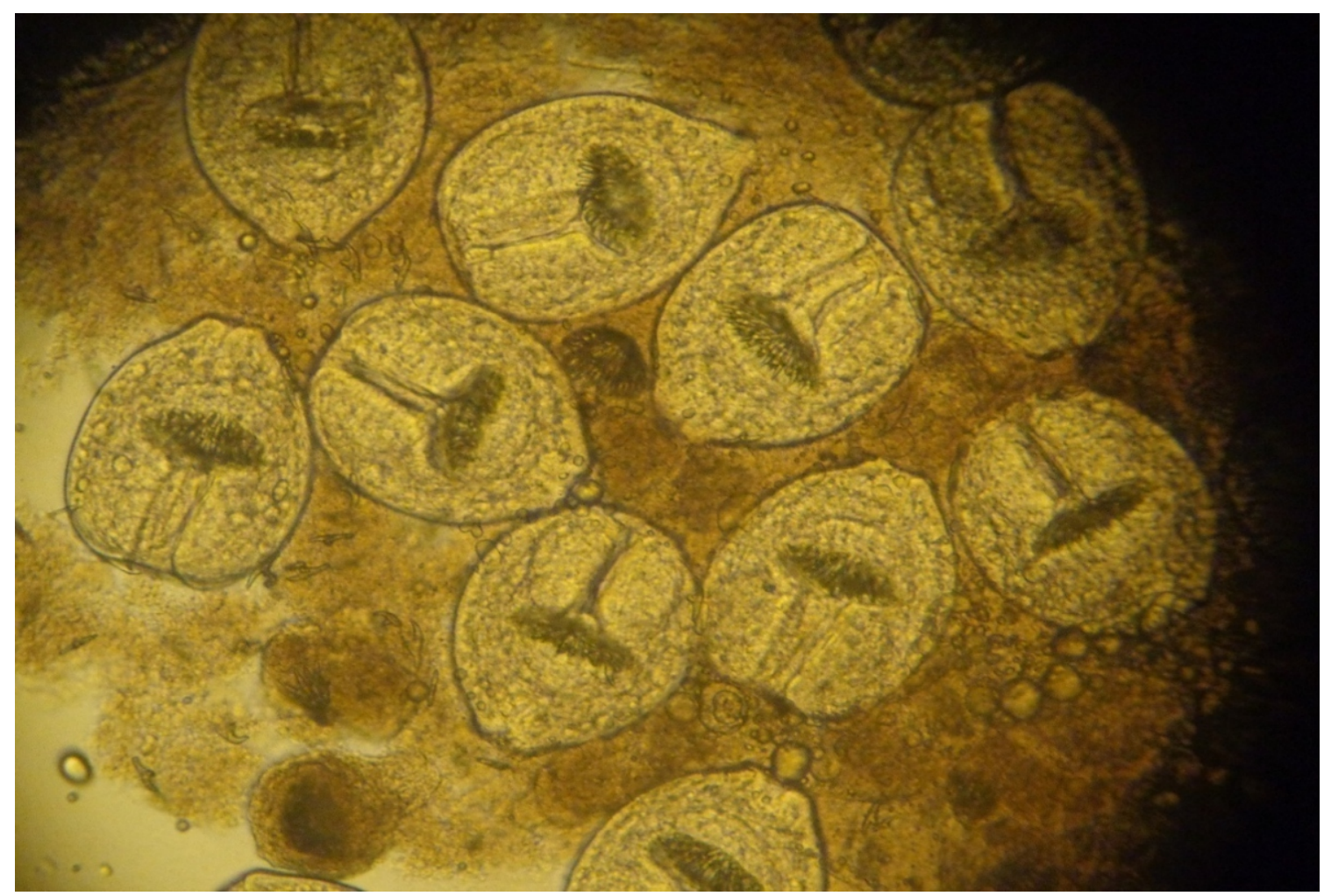

Figure 1: Vesicular Fluid Containing Numerous Protoscoleces (Hydatid Sand)

\section{DISCUSSION AND CONCLUSION}

Veterinary and medical problems have been associated with cystic hydatid disease in livestock and humans. Domestic intermediate host (cattle, camel, sheep, goats and buffaloes) are major reservoirs for the disease in humans.

In this study, the prevalence of hydatidosis was $1.73 \%$ out of the 404 camel examined, which is lower compared to a similar work carried out by Dada (1980) in the abattoirs in Kano, and Zaria (Northern Guinea zone), where hydatid cyst prevalence of $55.5 \%$ and $50.0 \%$ respectively were observed in camels. Magaji et al. (2011) in a retrospective study also reported a prevalence of $8.97 \%(\mathrm{n}=3545)$ in camels slaughtered at Sokoto central abattoir, which is also higher than that obtained in this survey. This could be due to environmental conditions that are conducive to the perpetuation of the parasite in those region which may be absent in this region. In a study conducted by Wachira et al., (1993) to determine the transmission dynamics of cystic Echinococcosis (CE), they found that eggs of $E$. granulosus could survive only a few hours under the high ambient temperatures of Turkana. However, when these eggs are exposed to sunlight and high temperatures, they became desiccated and did not hatch even when consumed by intermediate hosts. This may also be a contributing factor to the low prevalence as the ambient temperature in Maiduguri could rise up to $45^{\circ} \mathrm{C}$ thereby causing desiccation to the eggs and resulting to low prevalence. In addition, the low prevalence may also be attributed to periodic treatment of ruminants with anthelmintics by the pastoralists who now patronize veterinary services. Furthermore, increase in stray dog population and the close contacts with animals may also assist the transmission of CE in the affected regions with resultant high prevalence in such areas.

The lungs were found to be more infected compared to the liver and kidney. This agrees with earlier reports (Biu and Abagwe, 2001; Fathi et al., 2011). In addition, lungs and liver possess the first great capillary sites encountered by the migrating Echinococcus oncosphere (hexacanth embryo) which adopt the portal vein route and primarily negotiate hepatic and pulmonary filtering system sequentially before any other peripheral organ is involved (Ibrahem, 2010). High cyst fertility has been found to occur in the lungs and cysts found in the lungs have been shown to be more fertile 
than that found in other organs. Himonas (1987) postulated that the relatively softer consistency of lung tissue allows the easier development of the cyst in lungs than any other organs.

In conclusion, the prevalence of the disease in the dromedary camel (Camelus dromedarius; one humped camel) in this study area is low. However, the low prevalence is of significance largely from the zoonotic point of view and the role camels play as being an important source of meat in this part of the country.

\section{REFERENCES}

Adamu, N.B. and Ajogi I. 1998. Hydatidosis of one-humped Camel (Camelus dromendarus) at slaughtered in Maiduguri abattoir. Israel Journal of Veterinary Medicine 53 (1):16-18.

Biu, A.A. and Abagwe, S.A. 2001Prevalence of hydtidosis amongst food animals in semiarid Northeastern Nigeria. Bioscience Research Communication 85-91.

Biu, A.A. and Abbagana A. 2007. Prevalence of Paramphistomes in camels slaughtered at Maiduguri abattoir, Nigeria. Nigeria Journal of Parasitology 28(1):44-46.

Dada, B.J. and Belino, E.D. 1978. Prevalence of hydatidosis and cysticercosis in slaughtered livestock in Nigeria. The Veterinary Record 103:311-312.

Dada, B. J. O. 1980. Teaniasis, Cysticercosis and Echinococcosis/hydatidosis in Nigeria: III- prevalence of bovine and porcine cysticercosis, and hydatid cyst infection based on joint examination of slaughtered food animals. Journal of Helminthology 54: 293-297.

Dorman A.E.1986. Aspects of the husbandry and management of the genus Camelas. In: A.J. Higgins, (ed.), The Camel in Health and Disease, Baillier Tindall, London 3-20.

Fathi, S., Dehaghi, M.M. and Radfar, M.H. 2011. Fertility and viability rates of hydatid cysts in camels slaughtered in Kerman region, southeast of Iran. Scientific Parasitology 12(2): $77-83$.

F.A.O.1982.Echinococcus/ hydatidosis: surveillance, prevention and control. FAO/UNEP/WHO guidelines. FAO Animal Production and Health Paper No.
29. Rome.

Himonas, C. 1987. The fertility of hydatid cyst in food animals in Greece. Helminth zoonoses. Martinus Nijhoff publishers, Netherlands.

Ibrahem, M.M. 2010. Study of cystic echinococcosis in slaughtered animals in Al Baha region, Saudi Arabia: Interaction between some biotic and abiotic factors. Acta Tropica 113:26-33.

Kassem, H.H and Gdoura, N.K 2006. Hydatidosis in camels (Camelus dromedarius) slaughtered at Sirt Abattoir, Libya. Journal of Egypt Society of Parasitology 36(2):1-10.

Macpherson, C.N.L., Zeyle, E. and Roming T. 1985. An echinococcosis pilot control programme for Northwest Turkana, Kenya. Annals of Saudi Medecine 78: 188192.

Magaji, A .A., Oboegbulem, S. I, Daneji, A. I., Garba, H. S., Salihu, M. D., Junaidu, A. U., Mohammed, A. A., Lawal, M., Aminu S., Yakubu, Y. and Mamuda, A. 2011. Incidence of Hydatid cyst disease in food animals slaughtered at Sokoto Central Abattoir, Sokoto State, Nigeria. Veterinary World 4(5): 197-200.

Moghaddar, N., Oryan, A. and Hanifpour, M.R 1992. Helminths recovered from the liver and lungs of camels with special reference to their incidence and pathogenesis in Shiraz, Islamic Republic of Iran. Indian Journal of Animal Science 62:1018-1023.

Musa, A.W. and Pindar, T.Y. 2005. Geographical history of Borno State; by the Borno State Ministry for Local Government and Chieftaincy Affairs. ALGON Diary.

Okolugbo, B. C., Luka, S. A. and Ndams, I. S. 2013. Hydatidosis of camels and cattle slaughtered in Sokoto State, Nothern Nigeria. Food Science and Quality Management 21; 40- 46.

Osuobeni, E.P. and Hamidzada W.A. 1999. Ultrasonographic determination of the dimensions of ocular components in enucleated eyes of the one-humped camel (Camelus dromedarius). Research in Veterinary Science 67(2): 125-9.

Raush, R.L. 1986. Life cycle patterns and geographic distribution of Echinococcus 
species. In: The biology of Echinococcus and hydatid disease R.C.A. Thompson, ed. George Allen and Unwin London, UK, 44-80.

Soulsby, E.J.L. 1982. Helminths, Arthropods and Protozoans of Domesticated Animals (7th ed) Baillier Tindall, London. 809.

Schantz, P.M. 1990. Parasitic zoonosis in perspective. International Journal of Parasitology 21 (2): 165-166.
Srivastava, G.C., Daka, D.K. and Chiabra R.C. 1983. Incidence of Hydatidosis in Ruminants. Indian Journal of Animal Science $53(2): 202-205$.

Wachira, T. M., Bowles, J., Zeyhle, E., \& McManus, D. P. 1993. Molecular examination of the sympatry and distribution of sheep and camel strains of Echinococcus granulosus in Kenya. The American Journal of Tropical Medicine and Hygiene 48(4):473-479. 